\title{
Quality assurance in undergraduate dental institutions of Bangladesh: Views of stakeholders
}

\author{
Dr. Md. Mahafuzur Raihan ${ }^{1}$, Professor Dr. Syeda Afroza ${ }^{2}$, Professor Dr. Md. Humayun Kabir Talukder ${ }^{3}$, \\ Brig. Gen. Md. Abdullah Al Harun', Dr. Md. Immam Hossin', Md. Rasel Ahmad
}

\begin{abstract}
This cross-sectional study was conducted to find out the views of some stakeholders in regarding the current quality assurance activities in different government and non-government dental institutions of Bangladesh. Students, intern doctors, teachers and head of the institutions were the respondents. Semi-structured self-administered questionnaire, interview schedules and a checklist were used for data collection. The sampling technique was convenience and purposive. The study was conducted in 2015 and 2016.

The study revealed that teachers were satisfied with the overall educational environment, but students are not certain about this mater and the students' opinion were negative in regards to hostel and library facilities. Only few teachers were engaged in research activities in which authorities do not provide any assistance. Almost all dental institutions are deficient in their quality assurance activities. Other than academic council most of the quality assurance bodies are absent or non-functioning. The study recommends that quality assurance activities in undergraduate dental institutions in Bangladesh should be strengthened and it should be evaluated by the national quality assurance body.
\end{abstract}

Key Words: Quality Assurance, Stakeholders view, Educational environment.

\section{Introduction}

There is no regulatory definition for quality assurance. Quality assurance can be described as 'systematic, dataguided activities designed to bring about immediate (or nearly immediate) improvements in health care delivery'. The combined efforts of everyone to make changes will potentially lead to better patient outcomes, better system performance, and better professional development ${ }^{2}$.

Improved quality in dental education is required for a number of reasons:

1. Quality is an essential component of any service and production process. In order to be accountable to consumers, public and government, acceptable procedures on evaluation and quality assurance are necessary,

2. Quality is an important internal and external measure of

${ }^{1}$ Associate Professor and Head, Department of Oral Anatomy

Saphena Women's Dental College, Dhaka

${ }^{2}$ Professor, Department of Paediatrics, Shaheed Suhrawardy

Medical College, Dhaka.

${ }^{3}$ Professor, Curriculum Development \& Evaluation

Centre forMedical Education (CME), Mohakhali, Dhaka.

${ }^{4}$ Director, BSMMU, Dhaka

${ }^{5}$ Dental surgeon, Department of Oral and Maxillofacial Surgery

Dhaka Dental College Hospital

${ }^{5}$ Dental surgeon and Medical Educationist

Address of correspondence: Dr. Md. Mahafuzur Raihan

Associate Professor and Head, Department of Oral Anatomy

Saphena Women's Dental College, Dhaka

Email: mahfuzur.raihan@gmail.com organization's performance,

3. International cooperation requires greater insight into the quality of teaching programs and graduates.

In order to improve the dental education in systemic and effective way activities for quality assurance is the first step on the way to quality improvement. Quality improvement is a continuing and dynamic process to review, critique and change in order to make medical education better. Quality is not a goal but a process. We want quality in educational outcome, quality in educational program, quality in students' assessment and quality of teachers. It can be achieved by evaluation, follow up and obtaining international standard and guidelines ${ }^{4}$.

Dental education is fast becoming an international resource. It is manifested by growing number of migrating dentists and cross boarder education providers. On the other hand, new dental colleges of doubtful quality are increasing. This situation accentuates the need to define standard that will be effective and transparent.

In the rapidly developing world of global dental education it is vital that the standards of educational resources, staff and new graduates are agreed, established and maintained by the dental education community. The barriers in dental education and dental health care can be broken by the interactions between dental educators. And the situation can be improved for the benefits of all ${ }^{5}$.

For the delivery of quality oral health care, perhaps the most fundamental issue is the education and training of the undergraduate students who will become dentists and ultimately provide that care. For maintaining the required ultimately provide that care. For maintaining the required

Bangladesh Journal of Medical Education 2017;8(2):7-11. (C) 2017 Raihan et al., publisher and licensee Association for Medical Education. This is an Open Access article which permits unrestricted non-commercial use, provided the original work is properly cited. 
standards of dental education and consequently oral health care delivery, activities towards quality assurance must be sorted out and strengthen.

Quality assurance is responsibility of all stakeholders and their views will help to change, strengthen, widen or improve the quality of dental education and ultimately the oral health care delivery system for the benefit of all.

\section{Materials and methods}

This cross-sectional study was conducted to find out the views of some stakeholders in regarding the current quality assurance activities in undergraduate dental institutions of Bangladesh. Four (4) government and six (6) nongovernment dental institutions were included in the study. Students, teachers and head of the institutions were the respondents. Sample size were 400 for students, 94 for teachers and 10 for the head of the institutions. Two semistructured self-administered questionnaire (one for students and one for teachers), interview schedules (for head of the institutions) and a checklist were used for data collection.
The sampling technique was convenience and purposive. The study was conducted in 2015 and 2016.

\section{Results}

Table 1 shows that about the statement of students' opinion were taken by the teacher during teaching, out of 400 respondents $37 \%$ (148) agreed and $6.8 \%$ (27) strongly agreed with the statement. But 30.8\% (123) disagreed and $13 \%$ (52) strongly disagreed with the statement.

Out of 400 students/intern doctors $39.1 \%$ respondents were not satisfied with the development of their knowledge, $37.6 \%$ were satisfied and $23.5 \%$ were undecided about their development of knowledge. Out of 396respondents, majority (43\%) respondents agreed that they were satisfied with the development of their practical skills and 33.3\% disagreed with the statement. Out of 326 respondents, majority $52.7 \%$ were satisfied with the development of their clinical skills and $33.8 \%$ were not satisfied with the development of their clinical skills.

Table-1: Distribution of students'/intern doctors' level of satisfaction regarding educational environment of their institution

\begin{tabular}{|c|c|c|c|c|c|c|c|}
\hline \multirow{2}{*}{$\begin{array}{l}\text { Statements in relation to educational } \\
\text { environment }\end{array}$} & \multicolumn{6}{|c|}{ Frequency (\%) } & \multirow[t]{2}{*}{ Total } \\
\hline & \begin{tabular}{|c|} 
Strongly disagree \\
F $(\%)$
\end{tabular} & \begin{tabular}{|l|} 
Disagree \\
F $(\%)$
\end{tabular} & $\begin{array}{l}\text { Undecided } \\
\text { F (\%) }\end{array}$ & $\begin{array}{l}\text { Agree } \\
\text { F (\%) }\end{array}$ & \begin{tabular}{|} 
Strongly agree \\
F $(\%)$
\end{tabular} & $\begin{array}{c}\text { Strongly agree } \\
\mathrm{F}(\%)\end{array}$ & \\
\hline $\begin{array}{l}\text { Students' opinion were taken in } \\
\text { consideration by the teachers during } \\
\text { teaching }\end{array}$ & $52(13)$ & $123(30.8)$ & $50(12.5)$ & $148(37)$ & $27(6.8)$ & $27(6.8)$ & 400 \\
\hline $\begin{array}{l}\text { I am satisfied with the development of } \\
\text { my knowledge }\end{array}$ & $39(9.8)$ & $117(29.3)$ & $94(23.5)$ & $133(33.3)$ & $17(4.3)$ & $17(4.3)$ & 400 \\
\hline $\begin{array}{l}\text { I am satisfied with the development of } \\
\text { my practical skills }\end{array}$ & $33(8.3)$ & $99(25)$ & 94 (23.7) & $163(41.2)$ & $7(1.8)$ & $7(1.8)$ & 396 \\
\hline $\begin{array}{l}\text { I am satisfied with the development of } \\
\text { my clinical skills till now }\end{array}$ & $38(11.7)$ & $72(22.1)$ & $53(16.3)$ & $162(49.7)$ & $1(3)$ & $1(3)$ & 326 \\
\hline $\begin{array}{l}\text { Overall formative assessment was } \\
\text { satisfactory }\end{array}$ & $41(10.3)$ & $86(21.5)$ & $80(20)$ & $189(47.3)$ & $4(1)$ & $4(1)$ & 400 \\
\hline $\begin{array}{l}\text { Overall summative assessment was } \\
\text { satisfactory }\end{array}$ & $53(10.3)$ & $64(16)$ & $101(25.3)$ & $174(43.5)$ & $8(2)$ & $8(2)$ & 400 \\
\hline $\begin{array}{l}\text { Overall condition of the classroom } \\
\text { was satisfactory }\end{array}$ & $38(9.5)$ & $56(14)$ & $67(16.8)$ & $233(58.3)$ & $6(1.5)$ & $6(1.5)$ & 400 \\
\hline $\begin{array}{l}\text { Overall library facility was } \\
\text { satisfactory }\end{array}$ & $33(8.4)$ & $99(25.2)$ & $53(13.5)$ & $190(48.3)$ & $18(4.6)$ & $18(4.6)$ & 393 \\
\hline Overall hostel facility was satisfactory & $86(25.1)$ & $49(14.3)$ & $77(22.5)$ & $96(28.1)$ & $34(9.9)$ & $34(9.9)$ & 342 \\
\hline $\begin{array}{l}\text { Overall teaching was in favor of my } \\
\text { learning }\end{array}$ & $59(14.9)$ & $71(18)$ & $63(15.9)$ & $179(45.3)$ & $23(5.8)$ & $23(5.8)$ & 395 \\
\hline $\begin{array}{l}\text { Teachers were very much sincere to } \\
\text { provide advice and counseling }\end{array}$ & $46(11.5)$ & $108(27.1)$ & $60(15)$ & $146(36.6)$ & $39(9.8)$ & $39(9.8)$ & 399 \\
\hline $\begin{array}{l}\text { There were unbiased behavior of the } \\
\text { teachers to students }\end{array}$ & $65(16.3)$ & $67(16.8)$ & $81(20.3)$ & $171(42.8)$ & $16(4)$ & $16(4)$ & 400 \\
\hline $\begin{array}{l}\text { Relationship among students were } \\
\text { very good }\end{array}$ & $20(5)$ & $92(23)$ & $63(15.8)$ & $183(45.8)$ & $42(10.5)$ & $42(10.5)$ & 400 \\
\hline $\begin{array}{l}\text { Overall relationship between teachers } \\
\text { and students were very good }\end{array}$ & $18(4.5)$ & $95(23.8)$ & $77(19.3)$ & $171(42.8)$ & $39(9.8)$ & $39(9.8)$ & 400 \\
\hline
\end{tabular}

Bangladesh Journal of Medical Education 2017;8(2):7-11. 
Out of 400 respondents, majority (48.3\%) agreed that overall formative assessment was satisfactory and 31.8\% disagreed with the statement. About the statement of overall summative assessment was satisfactory, majority (45.5\%) agreed with the statement and $26.3 \%$ disagreed.

About the statement of overall classroom condition was satisfactory, out of 400 respondents majority $(59.8 \%)$ agreed with the statement. Out of 393 respondents, majority $(52.9 \%)$ agreed that overall library facility was satisfactory. Out of 342 respondents, $39.4 \%$ disagreed that the overall hostel facility was satisfactory and $38 \%$ mentioned that hostel facility was satisfactory.

Out of 395 respondents, majority (51.1\%) agreed that the overall teaching was in favor of their learning. About the statement of teachers were very sincere to provide advice and counseling, out of 399 respondents, $46.4 \%$ agreed and $38.6 \%$ disagreed. Out of 400 respondents $46.8 \%$ students mentioned that there were unbiased behavior of the teachers to students, but $33.1 \%$ disagreed that.

Out of 400 respondents, majority (56.3\%) mentioned that the relationship among students were very good and $28 \%$ disagreed with that. About the statement of overall relationship between teachers and students were very good, out of 400 respondents, majority $(52.6 \%)$ respondents responded positively, but $28.3 \%$ respondents did not agreed with the statement.

Table 2: Distribution of teachers' level of satisfaction regarding the educational environment of the institution they belong

\begin{tabular}{|c|c|c|c|c|c|c|c|}
\hline \multirow{2}{*}{$\begin{array}{l}\text { Statements in relation to educational } \\
\text { environment }\end{array}$} & \multicolumn{6}{|c|}{ Frequency $(\%)$} & \multirow{2}{*}{\begin{tabular}{|c} 
Total \\
69 \\
\end{tabular}} \\
\hline & $1(1.4 \%)$ & $1(1.4 \%)$ & $9(13 \%)$ & $54(78.3 \%)$ & $4(5.8 \%)$ & $4(5.8 \%)$ & \\
\hline $\begin{array}{l}\text { I am very satisfied regarding availability of } \\
\text { teaching/learning aids }\end{array}$ & $9(10 \%)$ & $24(26.7 \%)$ & $11(12.2 \%)$ & $32(35 \%)$ & $14(15.6 \%)$ & $14(15.6 \%)$ & 90 \\
\hline $\begin{array}{l}\text { Educational environment is supportive for } \\
\text { teaching }\end{array}$ & $15(16.7 \%)$ & $7(7.8 \%)$ & $8(8.9 \%)$ & $48(53.3 \%)$ & $12(13.3 \%)$ & $12(13.3 \%)$ & 90 \\
\hline I am satisfied with my teaching capability & $2(2.2 \%)$ & $10(10.8 \%)$ & $13(14 \%)$ & $58(62.4 \%)$ & $10(10.8 \%)$ & $10(10.8 \%)$ & 93 \\
\hline The environment is supportive for research & $2(8.3 \%)$ & $9(37.5 \%)$ & $1(4.2 \%)$ & $12(50 \%)$ & - & - & 24 \\
\hline $\begin{array}{l}\text { Authorities provide assistance in my research } \\
\text { work }\end{array}$ & $2(10.5 \%)$ & $8(42.1 \%)$ & $1(5.3 \%)$ & $6(31.6 \%)$ & $2(10.5 \%)$ & $2(10.5 \%)$ & 19 \\
\hline $\begin{array}{l}\text { I am satisfied with the learning of clinical skills } \\
\text { by my students }\end{array}$ & $2(3.1 \%)$ & $4(6.3 \%)$ & $4(6.3 \%)$ & $42(65.6 \%)$ & $12(18.8 \%)$ & $12(18.8 \%)$ & 64 \\
\hline $\begin{array}{l}\text { Relationship between teachers and students are } \\
\text { very good }\end{array}$ & $5(5.4 \%)$ & $4(4.3 \%)$ & $62(66.7 \%)$ & $22(23.7 \%)$ & - & - & 93 \\
\hline
\end{tabular}

Table 3: Distribution of dental institutions by the presence of the quality assurance bodies as per information provided by authority

\begin{tabular}{|l|c|c|c|}
\hline $\begin{array}{l}\text { Different bodies of quality } \\
\text { assurance }\end{array}$ & \multicolumn{3}{|c|}{$\begin{array}{l}\text { Opinion of the authorities } \\
\text { about the quality } \\
\text { assurance bodies }\end{array}$} \\
\hline & $\begin{array}{c}\text { Yes } \\
\mathbf{n}(\%)\end{array}$ & $\begin{array}{c}\text { No } \\
\mathbf{n}(\%)\end{array}$ & $\begin{array}{c}\text { Total } \\
\mathbf{n}(\%)\end{array}$ \\
\hline Academic council & $9(90)$ & $1(10)$ & $10(100)$ \\
\hline Academic coordination committee & $3(30)$ & $7(70)$ & $10(100)$ \\
\hline Phase coordination committee & $3(30)$ & $7(70)$ & $10(100)$ \\
\hline Subject coordinator & $7(70)$ & $3(30)$ & $10(100)$ \\
\hline Students' representatives & - & $10(100)$ & $10(100)$ \\
\hline $\begin{array}{l}\text { Faculty development and review } \\
\text { committee }\end{array}$ & $1(10)$ & $9(90)$ & $10(100)$ \\
\hline External examiners report & - & $10(100)$ & $10(100)$ \\
\hline Review visit team of pair college & - & $10(100)$ & $10(100)$ \\
\hline
\end{tabular}

Table 3 shows that out of $10(100)$ dental institutions $9(90 \%)$ had academic council, 7 (70\%) institutions did not have academic coordination committee and only $3(30 \%)$ had phase coordinator committee. Subject coordinator were not present in $30(30 \%)$ institutions and only $1(10 \%)$ institutions had faculty development committee. No dental institutions had students' representatives, external examiners' report and review visit team of pair college.

\section{Discussion}

This descriptive cross-sectional study was carried out in 10 dental institutions of Bangladesh to find out the view of the stakeholders about the quality assurance in undergraduate dental institutions.

Among the studied students/intern doctors 39.1\% respondents were not satisfied with their development of knowledge, but $37.6 \%$ were satisfied. Majority students/intern doctors $50.7 \%$ agreed that they were satisfied with the development of their clinical skills, but

Bangladesh Journal of Medical Education 2017;8(2):7-11. 
$33.8 \%$ responded negatively and $16.3 \%$ remained undecided with the statement (Table 1). So, no definite opinion can be revealed regarding the development of knowledge or clinical skills.

Halder (2015) found that regarding achievement of the students no definite opinion could be revealed about development of clinical skills (mean 2.96). Regarding the development of skill $35.8 \%$ students reported positively and $33.3 \%$ students responded negatively ${ }^{6}$. Similar type of findings were reported by Rouf (2012) regarding achievement of the students. Thirty four percent $(34 \%)$ students affirmed that they were satisfied with their development of knowledge and 39.4\% students felt that their problem solving skills were well developed. A significant number of students $(32.2 \%$ and $28.1 \%)$ told that their development of knowledge and skill were not satisfactory respectively ${ }^{7}$. Similar result was found in this study.

In this study, $48.3 \%$ students/intern doctors responded positively to the overall formative assessment and $31.8 \%$ responded negatively. On the other hand, 45.5\% respondents were satisfied with the overall summative examination, $26.3 \%$ were not satisfied and $25.3 \%$ were neither satisfied nor dissatisfied. So, no definite opinion could be revealed about overall formative or summative assessment. This study findings differed from the findings of medical colleges.

In his study, Halder (2015) found that majority of the students were satisfied about the present system of assessment and examination. The response of the students in relation to formative assessment was $68.6 \%$ and summative examination $73.4 \%$. Same kind of findings were reported by Saha $(2013)^{8}$.

Majority of the students/intern doctors, 39.4\% respondents were not satisfied with the overall hostel facilities.

$50.6 \%$ teachers were satisfied regarding the availability of teaching/learning aids, $73.2 \%$ teachers were satisfied with their teaching capability, $66.6 \%$ mentioned that educational environment is supportive for teaching (Table 2) and 51.2\% students/intern doctors mentioned that overall teaching was in favor of their learning (Table 1).

About the statement of overall relationship between teachers and students were very good, majority teachers $66.7 \%$ remained undecided, $23.7 \%$ responded positively and $9.7 \%$ responded negatively (Table 2 ). With the same statement $52.6 \%$ students responded positively and $28.3 \%$ responded negatively (Table 1). 50\% teachers mentioned that educational environment is supportive for research and $52.6 \%$ teachers mentioned that the authority do not provide any assistance in their research work.

During taking opinion of the authorities regarding different quality assurance bodies, it was found that $90 \%$ dental institutions had academic council and 30\% institutions had academic coordination committee. Only $10 \%$ institution had faculty development and review committee. No dental institutions had students' representatives, external examiners' report and review visit team of pair College (Table 3).

A cross sectional study conducted by Talukder et al (2010) to assess the teachers' knowledge about ongoing quality assurance scheme (QAS) at different medical and dental colleges in Bangladesh it was found that QAS is fully functioning in $46.5 \%$ colleges, partially functioning in $45.9 \%$ colleges, non-functioning in $3.9 \%$ colleges and absent in 3.6\% colleges. In a similar study Halder (2015) found that $100 \%$ medical colleges had all the committees of QAS like, academic council, academic coordination committee, phase coordination committee and subject coordinators. With the passage of time the condition had improved in case of medical colleges due to implementation of QAS and by the efforts taken by DGHS, CME and all other concerned to create awareness sincerity among the faculty to improve the quality of medical education (Halder 2015).

As QAS was practically not working in the dental institutions, there were lack of awareness for the improvement of quality assurance activities. As a consequence, there are scarcity of the quality assurance bodies and most of them are partially functional or nonfunctional.

\section{Conclusion}

This descriptive study was carried out to find out the views of stakeholders about the prevailing quality assurance activities in undergraduate dental institutions of Bangladesh. From the result of the study the following conclusion can be drawn.

Teachers were satisfied with the overall educational environment, but students are not certain about this mater. The students' opinion were negative in regards to hostel and library facilities. This may be due to lack of regular feedback from the students or taking biased feedback.

Only few teachers were engaged in research activities and most of the authorities do not provide any assistance in the research work.

Almost all dental institutions are deficient in their quality assurance activities. Other than academic council most of the quality assurance bodies are absent or non-functioning. Majority of the institutions did not have any faculty development and review committee, or even faculty development program. No dental institutions have students' representatives in any committee.

Quality education is the responsibility of all the teachers, students, administrators and management of the institution. Our ultimate goal should be to improve the quality of oral health care and that will happen only if we take care of the quality assurance activities of dental institutions. 


\section{References}

1. Lynn J et al. 2007, The ethics of using quality improvement methods in Health care, Annals of Internal Medicine, vol. 146(9), pp. 666-673.

2. Lo B, Field MJ, ED 2009, Conflict of Interest in Medical Research, Education, and Practice, National Academies Press, Washington, D.C.

3. Rohlin M, Petersson K, Svensater G 1998, The Malmo model: a problem-based learning in undergraduate dental education, Eur J Dent Educ, vol. 2, issue 3, pp. 103-114.

4. Kulike K 2004, Quality assurance and quality improvement: The students' perspective, German Medical Students Association, Website www.kulike vortrag(1).pdf. visited on 17.04.2016.

5. Hobson R, Rolland S 2007, Quality assurance, benchmarking, assessment and mutual recognition of qualifications, Global Congress on dental education, September 2007, chapter 2.3, pp. 3-21.
6. Halder BB 2015, Current practice of Quality Assurance Scheme (QAS) in different medical colleges of Bangladesh, Thesis for Masters in Medical Education, Bangabandhu Sheikh Mujib Medical University, Dhaka.

7. Rouf MA 2012, Situation analysis of classroom environment in some selected medical colleges pf Bangladesh, Thesis for Masters in Medical Education, Bangabandhu Sheikh Mujib Medical University, Dhaka.

8. Saha D 2013, Views of students and teachers regarding the existing practice of OSPE in $1^{\text {st }}$ phase of MBBS course in selected medical colleges of Bangladesh, Thesis for Masters in Medical Education, Bangabandhu Sheikh Mujib Medical University, Dhaka.

9. Talukder MHK, Nazneen R, Hossain MZ, Nargis T, Alam KK, Chowdhury IJ \& Parveen I 2010, QAS in Medical and Dental Colleges in Bangladesh- Teacher's knowledge, Bangladesh Journal of Medical Biochemistry, vol. 3, no 1, pp. 6-10.

Bangladesh Journal of Medical Education 2017;8(2):7-11. 